NOTAS

\title{
A MILAGROS MIER
}

\author{
Ma. Fernanda Ramírez*
}

De las personas que cambian al mundo hay dos tipos: las que lo cambian nadando contra la corriente, utilizando su fuerza ya sea física o mental para lograr un cambio fuerte y de golpe, y aquellas que cambian el mundo discreta, calladamente, día a día, paso a paso como lo hizo Milagros Mier. Tal vez ella nunca lo supo, pero cambió la manera de pensar y de actuar de muchos de nosotros.

Cada lunes, miércoles y viernes tenía un reto que enfrentar dentro de su salón de clases, intentar estar a su nivel, evitar que su inteligencia me inhibiera, procurar comprender todo lo que ella nos enseñaba, no sólo el contenido de los textos sino de la vida en general. Eran días en los que me sentía satisfecha de tener la oportunidad de convivir con una mujer de tal personalidad y seguridad que tan-

* Estudiante de Ciencia Política, $6^{\circ}$ semestre. Estudió Ideas I y II con la Dra. Mier. to me cautivaba, la que al menos para mí, cumplía con todas las demandas de lo que una mujer debe ser y representar. Una persona que siempre tenía la disposición de escuchar, de aconsejar. Una persona que en mi vida hizo una gran diferencia, porque en ella muchas veces encontré consejo, apoyo. Porque es una de las mujeres que tanto admiro, sus cualidades, su inteligencia, su agudeza, su humor y su gran pasión hacen que yo me esfuerce para ser una mejor persona, es mi margen. Su fortaleza, su energía y su seguridad me hacían acercarme más para tratar de descubrir en una de nuestras pláticas cuál era el secreto para lograr ser lo que ella era.

Hoy me encantaría tener las palabras exactas para describirla de tal modo que, aquellos que no tuvieron la oportunidad de conocerla, pudieran lograr una imagen verdadera y sentir la enorme admiración que tantos le teníamos, pero es muy difí- 
NOTAS

cil poder describir a una persona tan especial. "Congruencia, es la clave en esta vida" la escuché decir alguna vez.

Nunca voy a olvidar a Milagros Mier, la impresión que causó en mi vida es tan grande que siempre la voy a recordar. Agradezco enormemente el tiempo que dedicó a escucharme y aconsejarme.

Espero de verdad haber podido plasmar en estas palabras todo lo que me gustaría decirte. 